A $\underset{\text { publications }}{\mathrm{C}} \quad$ Rec. Nat. Prod. 14:3 (2020) 196-200

\title{
Two New 2(1H)-Pyrazinone Derivatives from the Plant Endophyte Streptomyces sp. KIB-H1992
}

\author{
Xiao-Yan Ma ${ }^{1,2}$, Zhouxin Zhang ${ }^{2}$, Li Wang ${ }^{2}$, Xinjun $\mathrm{Hu}{ }^{3}$, \\ Xingyong Liu ${ }^{* 1}$ and Sheng-Xiong Huang $* 2$
}

${ }^{1}$ Key Laboratory of Green Chemistry of Sichuan Institutes of Higher Education, and School of Chemical Engineering, Sichuan University of Science \& Engineering, Zigong, 643000, PR China

${ }^{2}$ State Key Laboratory of Phytochemistry and Plant Resources in West China, CAS Center for Excellence in Molecular Plant Sciences, Kunming Institute of Botany, Chinese Academy of Sciences, Kunming 650204, China

${ }^{3}$ Material Corrosion and Protection Key Laboratory of Sichuan province, and College of Mechanical Engineering, Sichuan University of Science \& Engineering, Zigong, 643000, PR China

(Received July 28, 2019; Revised September 12, 2019; Accepted September 19, 2019)

\begin{abstract}
Two new 2(1H)-pyrazinone derivatives, 3,6-diisopropyl-5-methylpyrazin-2(1H)-one (1) and 5(hydroxymethyl)-3,6-diisopropylpyrazin-2 $(1 H)$-one (2), were isolated from the fermentation broth of endophytic actinomycete Streptomyces sp. KIB-H1992. Their structures were established based on the detailed spectroscopic analyses, including ESI-MS, HR-ESI-MS, 1D and 2D NMR spectra.
\end{abstract}

Keywords: 2(1H)-pyrazinone derivatives; endophytic actinomycete; Streptomyces sp.; spectroscopic analyses. (C) 2020 ACG Publications. All rights reserved.

\section{Microorganism Material}

The strain designated KIB-H1992 was isolated from Cassia tora Linn., which was collected in Yuanjiang, Yunnan Province, China, in 2016. It was identified as Streptomyces sp. by a 16S rRNA gene sequence (GenBank accession no. MN180858), and showed a $100.0 \%$ identity to the Streptomyces mobaraensis strain NRRL B-3729 (GenBank accession no. NR_043830.1) and Streptomyces mobaraensis strain NBRC 13819 (GenBank accession no. NR_112524.1).

\section{Previous Studies}

Endophytes, ranging from fungi, bacteria and actinomycetes, are extremely diverse and source of functional metabolites with chemical and bioactive diversity [1-3]. More recently, Endophytes have attracted increasing attention in the discovery of natural products with potential physiological activity $[4,5]$. As part of our continuous efforts in screening for more secondary metabolites from endophytic microorganisms [6,7], two new 2(1H)-pyrazinone derivatives were obtained from the fermentation

E-Mail: sxhuang@mail.kib.ac.cn (S.-X. Huang); Phone:086-871-65215112 Fax: 086-871-65215112

E-Mail: liuxy@suse.edu.cn (X. Liu); Phone:086-13330818181 
broth of endophytic actinomycete Streptomyces sp. KIB-H1992. To our best knowledge, there are a variety of $2(1 H)$-Pyrazinone derivatives with diverse structures have hitherto been isolated and identified, and some of them possess potent biological activities [8-14].

\section{Present Study}

The strain KIB-H1992 was cultivated on ISP2 agar plates (malt extract $10 \mathrm{~g}$, agar 20 g, glucose 4 $\mathrm{g}$ and yeast extract $4 \mathrm{~g}$ in $1 \mathrm{~L}$ of water, $\mathrm{pH} 7.2$ ) at $30^{\circ} \mathrm{C}$ for five days. After that, it was transferred into $250 \mathrm{~mL}$ baffled Erlenmeyer flasks, each flask was filled with $50 \mathrm{~mL}$ of Tryptone Soy Broth $(30 \mathrm{~g} / \mathrm{L}$, $\mathrm{pH} 7.3 \pm 0.2)$, and cultivated on a rotary shaker $(200 \mathrm{rpm})$ at $30^{\circ} \mathrm{C}$ for one day. Fermentations were carried out in $1000 \mathrm{~mL}$ baffle Erlenmeyer flasks with liquots $(12.5 \mathrm{~mL})$ of the culture. Each flask was filled with $250 \mathrm{~mL}$ of medium consisting of $1 \%$ soluble starch $(\mathrm{w} / \mathrm{v}), 1 \%$ glucose $(\mathrm{w} / \mathrm{v}), 1 \%$ glycerol $(\mathrm{w} / \mathrm{v}), 0.5 \%$ tryptone $(\mathrm{w} / \mathrm{v}), 0.5 \%$ yeast extract $(\mathrm{w} / \mathrm{v})$ and $0.3 \% \mathrm{CaCO}_{3}(\mathrm{w} / \mathrm{v})$ in deionized water $(\mathrm{pH}$ 7.0), and cultured on rotary shaker $(200 \mathrm{rpm})$ at $30{ }^{\circ} \mathrm{C}$ for seven days.

The fermentation broth $(20 \mathrm{~L})$ was centrifuged $(4000 \mathrm{rpm}, 15 \mathrm{~min})$, the supernatant liquid was extracted with ethyl acetate $(6 \times 5 \mathrm{~L})$ and concentrated in vacuo to afford $2.5 \mathrm{~g}$ crude extract. The mycelium was extracted with acetone $(4 \times 0.5 \mathrm{~L})$, and the acetone was removed in vacuo to yield the aqueous concentrate, which was then extracted with ethyl acetate $(1 \mathrm{~L} \times 3)$ and concentrated to give $1.1 \mathrm{~g}$ crude extract. Both extracts were combined for further purification. The crude extract $(3.6 \mathrm{~g})$ was fractionated by flash column chromatography on silica gel eluting with petroleum ether/ethyl acetate (20:1 to $0: 1$ ) as the eluent to afford five fractions (Fr1-Fr5). Fr4 was sequentially separated using Sephadex LH-20 column with methanol as eluent into four subfractions (Fr4A-Fr4D). Fr4C was then subjected to semipreparative HPLC (Hitachi HPLC system, YMC-Triart C18 column, $250 \times 10 \mathrm{~mm}$, DAD detector), elution with 55\% methanol containing $0.1 \%$ acetic acid at a flow rate of $3 \mathrm{~mL} \mathrm{~min}{ }^{-1}$ gave $\mathbf{1}\left(t_{R}=24.1,9.1 \mathrm{mg}\right)$ and $2\left(t_{R}=13.5 \mathrm{~min}, 3.1 \mathrm{mg}\right)$.

3,6-diisopropyl-5-methylpyrazin-2(1H)-one (1): white powder. IR $\vee \max (\mathrm{KBr}): 3447,2964,2876$, $1636,1601,1468,1129,501 \mathrm{~cm}^{-1} .{ }^{1} \mathrm{H}$ NMR $\left(600 \mathrm{MHz}, \mathrm{CDCl}_{3}\right): \delta_{\mathrm{H}} 12.33(1 \mathrm{H}$, brs, $\mathrm{NH}), 3.37(1 \mathrm{H}, \mathrm{m}$, $\mathrm{H}-9), 3.02(1 \mathrm{H}, \mathrm{m}, \mathrm{H}-7), 2.30\left(3 \mathrm{H}, \mathrm{s}, \mathrm{H}_{3}-5^{\prime}\right), 1.32\left(6 \mathrm{H}, \mathrm{d}, J=7.2 \mathrm{~Hz}, \mathrm{H}_{3}-8\right.$ and $\left.\mathrm{H}_{3}-10\right), 1.24(6 \mathrm{H}, \mathrm{d}, J=$ $6.6 \mathrm{~Hz}, \mathrm{H}_{3}-11$ and $\left.\mathrm{H}_{3}-12\right)$; ${ }^{13} \mathrm{C}$ NMR $\left(150 \mathrm{MHz}, \mathrm{CDCl}_{3}\right): \delta_{\mathrm{C}} 159.9(\mathrm{C}-3), 156.7(\mathrm{C}-2), 138.4(\mathrm{C}-6)$, 127.1 (C-5), 30.6 (C-10), 28.5 (C-7), 20.2x2 (C-8 and C-9), 19.9×2 (C-11 and C-12), 18.8 (C-5'). HRESI-MS: $\mathrm{C}_{11} \mathrm{H}_{18} \mathrm{~N}_{2} \mathrm{O}$ at $m / z$ 195.1497 $[\mathrm{M}+\mathrm{H}]^{+}$, (calcd for $\left.\mathrm{C}_{11} \mathrm{H}_{18} \mathrm{~N}_{2} \mathrm{O} m / z: 195.1492\right)$.

5-(hydroxymethyl)-3,6-diisopropylpyrazin-2(1H)-one (2): white powder. IR $v_{\max }(\mathrm{KBr})$ : 3447, 2964, 2876, 1636, 1601, 1468, 1129, $501 \mathrm{~cm}^{-1} .{ }^{1} \mathrm{H}$ NMR $\left(600 \mathrm{MHz}, \mathrm{CDCl}_{3}\right): \delta_{\mathrm{H}} 12.0612 .06(1 \mathrm{H}, \mathrm{brs}, \mathrm{NH})$, $4.58\left(2 \mathrm{H}, \mathrm{s}, \mathrm{H}_{2}-5^{\prime}\right), 3.41(1 \mathrm{H}, \mathrm{m}, \mathrm{H}-9), 3.01(1 \mathrm{H}, \mathrm{m}, \mathrm{H}-7), 1.33\left(6 \mathrm{H}, \mathrm{d}, J=7.2 \mathrm{~Hz}, \mathrm{H}_{3}-8\right.$ and $\left.\mathrm{H}_{3}-10\right)$, $1.26\left(6 \mathrm{H}, \mathrm{d}, J=6.6 \mathrm{~Hz}, \mathrm{H}_{3}-11\right.$ and $\left.\mathrm{H}_{3}-12\right) ;{ }^{13} \mathrm{C}$ NMR $\left(150 \mathrm{MHz}, \mathrm{CDCl}_{3}\right): \delta_{\mathrm{C}} 160.2(\mathrm{C}-3), 157.1(\mathrm{C}-2)$, 139.3 (C-6), 128.1 (C-5), 60.1 (C-5'), 30.3 (C-10), 27.4 (C-7), 20.5×2 (C-8 and C-9), 19.9x2 (C-11 and C-12). HRESI-MS: $\mathrm{C}_{11} \mathrm{H}_{18} \mathrm{~N}_{2} \mathrm{O}_{2}$ at $\mathrm{m} / z 211.1439[\mathrm{M}+\mathrm{H}]^{+}$, (calcd for $\mathrm{C}_{11} \mathrm{H}_{18} \mathrm{~N}_{2} \mathrm{O}_{2}, \mathrm{~m} / z$ : 211.1441).
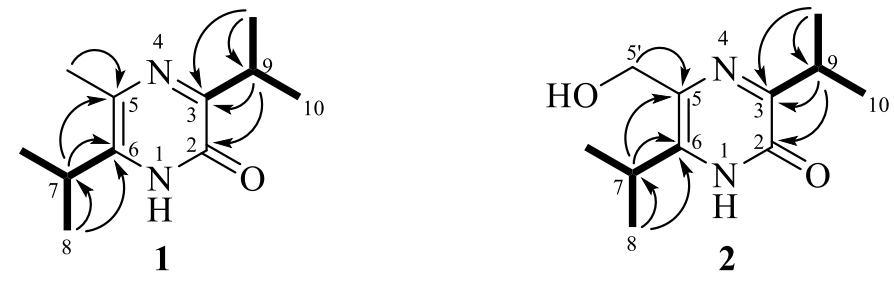

$\operatorname{COSY} \bigcirc \mathrm{HMBC}$

Figure 1. Structures of compounds 1-2, and their key 2D NMR correlations.

Compound $\mathbf{1}$ was obtained as white powder. The molecular formula was assigned as $\mathrm{C}_{11} \mathrm{H}_{18} \mathrm{~N}_{2} \mathrm{O}$ 
with four degrees of unsaturation by ESI-MS $\left(\mathrm{m} / z 195[\mathrm{M}+\mathrm{H}]^{+}, \mathrm{m} / z 217[\mathrm{M}+\mathrm{Na}]^{+}\right)$and HR-ESIMS $\left(m / z 195.1497[\mathrm{M}+\mathrm{H}]^{+}\right.$, calcd 195.1492). Its ${ }^{1} \mathrm{H}$ NMR spectrum (Table 1$)$ showed feature signals for two isopropyls at $3.02(1 \mathrm{H}$, hept, $J=7.2 \mathrm{~Hz}), 1.32(6 \mathrm{H}, \mathrm{d}, J=7.2 \mathrm{~Hz})$ and $3.37(1 \mathrm{H}$, hept, $J=6.6$ $\mathrm{Hz}), 1.24(6 \mathrm{H}, \mathrm{d}, J=6.6 \mathrm{~Hz})$, which was further identified by ${ }^{1} \mathrm{H}-{ }^{1} \mathrm{H}$ COSY spectrum. The ${ }^{13} \mathrm{C}$ NMR spectrum (Table 1), combined with the HSQC spectra, displayed the presence of 9 carbons (two carbon signal for $\mathrm{CH}_{3}$ of two isopropyls overlapped), including five methyl groups ( $\delta \mathrm{c} 18.8,20.0 \times 2$ and $20.2 \times 2$ ), two methines ( $\delta \mathrm{c} 28.5$ and 30.6), and four quaternary carbons including two olefin carbons ( $\delta$ c 127.1 and 138.4). The spectroscopic data indicated that the structure of 1 was highly similar to that of 3-isobutyl-6-isopropyl-5-methylpyrazin-2(1H)-one [15] with the major difference that an additional isopropyl group was appeared in $\mathbf{1}$ instead of the isobutyl group. The HMBC correlations from $\delta_{\mathrm{H}} 3.02(\mathrm{H}-7)$ to $\delta \mathrm{c} 127.1(\mathrm{C}-5)$ and $\delta \mathrm{c} 138.4(\mathrm{C}-6)$, and from $\delta_{\mathrm{H}} 1.32(\mathrm{H}-8)$ to $\delta \mathrm{c}$ 138.4 (C-6) indicated that an isopropyl was attached to $\mathrm{C} 6$, and suggested the presence of C5-C6 olefin. The methyl at $\mathrm{C} 5$ was assigned on the basis of the key HMBC correlations from $\delta \mathrm{H} 2.30\left(\mathrm{CH}_{3}-5\right)$ to $\delta \mathrm{c} 127.1(\mathrm{C}-5)$ and $\delta \mathrm{c} 138.4(\mathrm{C}-6)$, and the ${ }^{1} \mathrm{H}$ NMR data comparison of compound 1 at $\delta \mathrm{H} 2.30(3 \mathrm{H}$, s) with 3-isobutyl-6-isopropyl-5-methylpyrazin-2(1H)-one at $\delta \mathrm{H} 2.28(3 \mathrm{H}, \mathrm{s}), 3,6$-diisobutyl-5methylpyrazin-2(1H)-one at $\delta \mathrm{H} 2.29(3 \mathrm{H}, \mathrm{s})[15]$ and Sorazinone B [11] at $\delta \mathrm{H} 2.26(3 \mathrm{H}, \mathrm{s})$. The remaining isopropyl group was deduced to be attached to $\mathrm{C} 3$ by $\mathrm{HMBC}$ correlations from $\delta_{\mathrm{H}} 1.26(\mathrm{H}-$ $10)$ to $\delta \mathrm{C} 159.9(\mathrm{C}-3)$ and $\delta \mathrm{c} 30.6(\mathrm{C}-9)$, and from $\delta_{\mathrm{H}} 3.37(\mathrm{H}-9)$ to $\delta \mathrm{C} 156.7(\mathrm{C}-2)$ and $159.9(\mathrm{C}-3)$. Additionally, there is suggestive of an amido carbonyl group at $\mathrm{C} 2$ position and an imine carbon at $\mathrm{C} 3$ position from the above HMBC correlations. From the foregoing evidences, compound $\mathbf{1}$ was determined to be 3,6-diisopropyl-5-methylpyrazin-2(1H)-one (Figure 1). The structures of 3-isobutyl6-isopropyl-5-methylpyrazin-2(1H)-one, 3,6-diisobutyl-5-methylpyrazin-2(1H)-one and Sorazinone B were shown in the supporting information, and data comparison of compound $\mathbf{1}$ with these most similar compounds was also listed in supporting information.

Compound 2 was obtained as as white powder. Its ESI-MS spectrum showed a pseudo-molecular ion peak at $\mathrm{m} / z 211[\mathrm{M}+\mathrm{H}]^{+}$and a $\mathrm{m} / z 233[\mathrm{M}+\mathrm{Na}]^{+}$, and molecular formula was determined as $\mathrm{C}_{11} \mathrm{H}_{18} \mathrm{~N}_{2} \mathrm{O}_{2}$ by HRESI-MS at $m / z 211.1439[\mathrm{M}+\mathrm{H}]^{+}$(calcd for $\mathrm{C}_{11} \mathrm{H}_{18} \mathrm{~N}_{2} \mathrm{O}_{2}, 211.1441$ ). The ${ }^{1} \mathrm{H}$ and ${ }^{13} \mathrm{C}$ NMR spectra (Table 1) of compound $\mathbf{2}$ was very similar to those of compound $\mathbf{1}$; however, $\mathbf{2}$ showed the presence of an additional methylene $\left(\delta_{\mathrm{H}} 4.58, \delta_{\mathrm{C}} 60.1\right)$ instead of methyl $\left(\delta_{\mathrm{H}} 2.30, \delta_{\mathrm{C}} 18.8\right)$ in 1. In addition, comparing that the HR-ESI-MS with 1, there is 16 mass units more than that of it and suggestive of a hydroxymethyl at C5 position of $\mathbf{2}$. Thus, $\mathbf{2}$ was elucidated to be 5-(hydroxymethyl)3,6-diisopropylpyrazin-2(1H)-one (Figure 1).

Table 1. ${ }^{1} \mathrm{H}(600 \mathrm{MHz})$ and ${ }^{13} \mathrm{C}$ NMR $(150 \mathrm{MHz})$ data of compounds 1 and 2 in $\mathrm{CDCl}_{3}$.

\begin{tabular}{|c|c|c|c|c|}
\hline \multirow{2}{*}{ Position } & \multicolumn{2}{|r|}{1} & \multicolumn{2}{|r|}{2} \\
\hline & $\begin{array}{c}\delta \mathbf{c} \\
(\mathbf{p p m})\end{array}$ & $\delta_{\mathrm{H}}(\mathrm{ppm}, J$ in $\mathrm{Hz})$ & $\begin{array}{c}\delta \mathbf{c} \\
(\mathbf{p p m})\end{array}$ & $\delta_{\mathrm{H}}(\mathrm{ppm}, J$ in $\mathrm{Hz})$ \\
\hline 1 & & $12.33(1 \mathrm{H}, \mathrm{brs})$ & & $12.06(1 \mathrm{H}, \mathrm{brs})$ \\
\hline 2 & 156.7 & & 157.1 & \\
\hline 3 & 159.9 & & 160.2 & \\
\hline 5 & 127.1 & & 128.1 & \\
\hline $5-\mathrm{Me} / 5^{\prime}$ & 18.8 & $2.30(3 \mathrm{H}, \mathrm{s})$ & 60.1 & $4.58(2 \mathrm{H}, \mathrm{s})$ \\
\hline 6 & 138.4 & & 139.3 & \\
\hline 7 & 28.5 & $3.02(1 \mathrm{H}$, hept, $J=7.2 \mathrm{~Hz})$ & 27.4 & $3.01(1 \mathrm{H}$, hept, $J=7.2 \mathrm{~Hz})$ \\
\hline 8 & 20.2 & $1.32(6 \mathrm{H}, \mathrm{d}, J=7.2 \mathrm{~Hz})$ & 20.5 & $1.33(6 \mathrm{H}, \mathrm{d}, J=7.2 \mathrm{~Hz})$ \\
\hline 9 & 30.6 & $3.37(1 \mathrm{H}$, hept, $J=6.6 \mathrm{~Hz})$ & 30.3 & $3.41(1 \mathrm{H}$, hept, $J=6.6 \mathrm{~Hz})$ \\
\hline 10 & 19.9 & $1.24(6 \mathrm{H}, \mathrm{d}, J=6.6 \mathrm{~Hz})$ & 19.9 & $1.26(6 \mathrm{H}, \mathrm{d}, J=6.6 \mathrm{~Hz})$ \\
\hline
\end{tabular}




\section{Acknowledgments}

This work was financially supported by Applied Basic Research Program of Sichuan Province (2018JY0049), the National Natural Science Foundation of China (U1702285), the Opening Project of Key Laboratory of Green Chemistry of Sichuan Institutes of Higher Education (LZJ1806), the Opening Project of Material Corrosion and Protection Key Laboratory of Sichuan province (2018CL04), Cooperation Project of Wuliangye Group Co., Ltd. and Sichuan University of Science \& Engineering (CXY2019ZR013, CXY2019ZR003), and the Key Science and Technology Planning Project of Zigong City (2018YYJC03).

\section{Supporting Information}

Supporting Information accompanies this paper on http://www.acgpubs.org/journal/recordsof-natural-products.

\section{ORCID}

Xiao-Yan Ma: 0000-0002-4592-4800

Zhouxin Zhang: 0000-0002-6190-9731

Li Wang: 0000-0002-7004-4725

Xinjun Hu: 0000-0002-1433-5739

Xingyong Liu: 0000-0002-4782-7182

Sheng-Xiong Huang: 0000-0002-3616-8556

\section{References}

[1] G. Strobel, B. Daisy, U. Castillo and J. Harper (2004). Natural products from endophytic icroorganisms, J. Nat. Prod. 67, 257-268.

[2] R. X. Tan and W. X. Zou (2001). Endophytes: a rich source of functional metabolites, Nat. Prod. Rep. 18, 448-459.

[3] G. A.Strobel (2003). Endophytes as sources of bioactive products, Microbes Infect.5, 535-544.

[4] H. W. Zhang, Y. C. Songa and R. X. Tan (2006). Biology and chemistry of endophytes, Nat. Prod. Rep. 23, 753-771.

[5] S. Qin, K. Xing, J.H. Jiang, L.H. Xu and W.J. Li (2011). Biodiversity, bioactive natural products and biotechnological potential of plant-associated endophytic actinobacteria, Appl. Microbiol. Biot. 89, 457473.

[6] Z. Zhang, P. Cao, N.-N. Shang, J. Yang, L. Wang, Y. Yan and S.X. Huang (2019). Naphthomycinderived macrolactams with two new carbon skeletons from endophytic Streptomyces, Org. Chem. Front. 6, 177-182.

[7] R. Yang, J. Yang, L. Wang, J.-P. Huang, Z. Xiong, J. Luo, M. Yu, Y. Yan and S.X. Huang (2017). Lorneic acid analogues from an endophytic actinomycete, J. Nat. Prod. 80, 2615-2619.

[8] X. Peng, Y. Wang, T. Zhu and W. Zhu (2017). Pyrazinone derivatives from the coral-derived Aspergillus ochraceus LCJ11-102 under high iodide salt, Arch. Pharm. Res. 41, 187-191.

[9] L. A. Shaala, D.T. A. Youssef, J. M. Badr and S. M. Harakeh (2016). Bioactive 2(1H)-pyrazinones and diketopiperazine alkaloids from a tunicate-derived actinomycete Streptomyces sp., Molecules 21, 11161124.

[10] X. Bian, M. Shao, H. Pan, K. Wang, S. Huang, X. Wu, C. Xue, H. Hua, Y. Pei and J. Bai (2016). Paenibacillin A, a new 2(1H)-pyrazinone ring-containing natural product from the endophytic bacterium Paenibacillus sp. Xy-2, Nat. Prod. Res. 30, 125-130.

[11] R. Jansen, S. Sood, K. I. Mohr, B. Kunze, H. Irschik, M. Stadler and R. Müller (2014). Nannozinones and Sorazinones, unprecedented pyrazinones from Myxobacteria, J. Nat. Prod. 77, 2545-2552.

[12] Y. Takahashi, Y. Iinuma, T. Kubota, M. Tsuda, M. Sekiguchi, Y. Mikami, J. Fromont and J. Kobayashi (2011). Hyrtioseragamines A and B, new alkaloids from the Sponge hyrtios species, Org. Lett. 13, 628631. 
[13] K. Motohashi, K. Inaba, S. Fuse, T. Doi, M. Izumikawa, S. T. Khan, M. Takagi, T. Takahashi and K. Shin-ya (2011). JBIR-56 and JBIR-57, 2(1H)-pyrazinones from a marine sponge-derived Streptomyces sp. SpD081030SC-03, J. Nat. Prod. 74, 1630-1635.

[14] K. Hirano, T. Kubota, M. Tsuda, K. Watanabe, J. Fromont and J. Kobayashi (2000). Ma'edamines A and B, cytotoxic bromotyrosine alkaloids with a unique $2(1 H)$ pyrazinone ring from Sponge Suberea sp., Tetrahedron 56, 8107-8110.

[15] H. Taguchi, T. Yokoi, M. Tsukatani and Y. Okada (1995). Amino acids and peptides. XLI. Facile synthesis of 5-methyl-2(1H)-pyrazinone derivatives from ddipeptidyl chloromethyl ketones, Tetrahedron 51, 7361-7372.

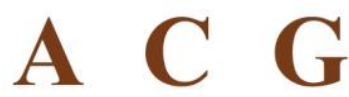

publications

(C) 2020 ACG Publications 